Oliver BAKRESKI

UDK: 355.45-021.383(497.7)

Original research paper

\title{
THE NATIONAL SECURITY SYSTEM OF THE REPUBLIC OF MONTENEGRO
}

\begin{abstract}
The national security system of the Republic of Montenegro is based upon the specifics of the Montenegrin country and is adjusted in such a manner that is able to respond to the contemporary security challenges. That said, it has to address to a great extent the threats and risks which the country faces on a national, regional and international plan. This signifies building an efficient system, functional and operative, for dealing with security threats to the country. The basic dilemmas which are subject of discussion in the paper itself refer to the issues "Whether the national security system could completely enforce the national security policy?" as well as the question "Whether Montenegro, because of the limited resources, has the adequate capacities for dealing with the security risks and threats?" These issues are always in the open row for which new answers are looked for.
\end{abstract}

Key words: MONTENEGRO, SECURITY, SYSTEM, SECURITY SYSTEM, POLICY, SECURITY POLICY.

\section{Introductory Remarks}

The Republic of Montenegro is a maritime country which is located in Southeastern Europe and borders with Serbia, Croatia, Bosnia and Herzegovina, Albania and Kosovo. According to certain sources, the name Montenegro is tied with the middle ages when the mountain Lovken and its foothills, as well as the area of the old Montenegrin mountains were covered with thick "black" forest. Montenegro is for the first time mentioned in 1276 when the ancient names are gradually replaced with this geographic and state area Duklja and Zeta. ${ }^{1}$ According to other sources, the name Montenegro is for the first time mentioned in the $\mathrm{XV}$ century, after the arrival of the Crnojevik dynasty on the throne of the former Serbian state Zeta. This territory fell under Ottoman rule in 1496 and became a part of the Skadar Sandžak. After a series of uprisings, the Montenegrin tribes fought for autonomy in the XVI century, and in the second half of the XVII century they also fought for the de facto autonomy of their mountainous territory. Ever since, Montenegro has had internal theocratic organization because the Cetinje metropolitans- archbishops were at the head of the secular rule. The transformati-

${ }^{1}$ Garašanin, M. (2018). Crna Gora do Doseljavanja Slovena. Montenegrina Digitalna Biblioteka Crnogorske Kulture [online] available at: http:/www.montenegro.yu/podaci/stanovnistvo.htm, (accessed 26/11/2017). 
on of the country to a secular principality comes up in 1852, and on the Berlin Congress, held in 1878, Montenegro is recognized as an independent state.

From 1918 until 1991 Montenegro is within the composition of Yugoslavia (Kingdom of SCS, FPRY, SFRY). After the discomposure of the SFRY, from 1992 to 2003, Montenegro was a constitutive element of the Federal Republic of Yugoslavia, and from 2003 until 2006 it was within the state union of Serbia and Montenegro. The independence referendum of Montenegro took place on May $21^{\text {st }} 2006$. This referendum was supported by more than $55 \%$ of the citizens of Montenegro, which was a precondition of the European Union to confirm and recognize its independence. Calling upon the results of the referendum votes, Montenegro formally announced its independence on June $3^{\text {rd }} 2006$ (CIA, The World Factbook: Montenegro, 2018). Italian sources name this country Montagna Negra, Montenegro or Monte Negro and hence is today's denomination Montenegro, which has entered into use in the Western European languages.

The area of the Montenegrin territory amounts to $13.812 \mathrm{~km}$ (ibidem). The coastal line amounts to 293, $5 \mathrm{~km}$, from which $52 \mathrm{~km}$ are a strip of beach. According to the data from July 2017, Montenegro has approximately 642,550 residents (ibidem). The data from the last census held in Montenegro in 2011 disclosed that $44.98 \%$ from the total population declared themselves as Montenegrins, $28.73 \%$ as Serbs, $8.7 \%$ as Bosnians, 4.91\% as Albanians, 3.31\% as Muslim, 0.97\% as Croats (Montenegro-Canada, Crnogorski popis, 2018). The Gross - domestic product for the year 2017 amounted to 10, 86 billion US\$. The Gross- domestic product per capita for 2017 amounted to 17.400 US\$ (CIA, The World Factbook: Montenegro, 2018).

According to its Constitution, the Republic of Montenegro is a civic, democratic, ecological and social justice country founded on the rule of law. In accordance with the principles and practice of the contemporary parliamentary states, the government in Montenegro is designated by the principle of division of the: legislative, executive and judicial branch. The Parliament (Skupština) as the legislative branch of power, acts autonomously and in reciprocal balance with the other branches of authority (executeve and judicial). The executive authority is enforced by the Government, and the judicial authority is performed by the courts.

The Republic of Montenegro is a member of numerous international organizations such as: the Organization of the UN, the Council of Europe, NATO, UNESCO, the International Monetary Fund (MMF), the World Health Organization, Interpol and other significant international and regional organizations. At this moment, Montenegro works intensively and expects to gain a full membership in the European Union in the coming years.

\section{NATIONAL SECURITY POLICY}

The basis of the national security policy of the Republic of Montenegro dates from the declaration of its independence in 2006. With the adoption of the National 
security Strategy the strategic directions of the development and the functioning of the national security system of the Republic of Montenegro are defined.

With the purpose of achieving the national interests and the security goals, regarding the democratic principles, Montenegro is conducting the rule of law and the orientation toward the European and the Euro-Atlantic integrations.

The strategic goals emanate from the existing vital and strategic interests and values of the Republic of Montenegro. The main strategic goals and interests for the national security policy are aimed toward: defence of the sovereignty, independence and territorial integrity of Montenegro; protection of the lives and assets of the citizens and economic goods; development of the defence capacities, integration in the EU, promotion of the policy of good neighbourly relations and cooperation on a regional and on a global scale; strengthening of the democracy, the rule of law and the complete protection of human and minority rights; complete legislative designation of the realm of national security in accordance with the Constitution, the international law and the international obligations which were accepted by Montenegro; strengthening of the capacities of Montenegro in the fight against terrorism, organized crime and corruption, as well as strengthening of the border security; increase of the transparency of the defence sector and the civil control over the army; improvement of the capacities of the institutions for crisis management caused by natural, technical-technological, biological, nuclear and other disasters; contribution to world peace by expressing international solidarity, active participation in the combat against terrorism and non-proliferation of weapons of mass destruction, mine clearance, humanitarian and peace operations and ability to use its terrestrial, aerial and naval space for support of the missions led by the UN, NATO, EU and OBSE; achievement of a sustainable economic development through the increasing economic liberty and strengthening of the role of the enterprises; improvement of the living standard of the citizens with provision of quality services through the system of efficient education, health and social protection; enabling of conditions for preservation of tradition, culture, language, national identity and customs; securing protection of the information systems of Montenegro from an unauthorized access or modification of information; preservation and protection of the environment and the natural habitat and promotion of sustainable development [Strategija nacionalne bezbjednosti, ("Sl. list Crne Gore", br. 75/08)].

Based on the strategic evaluation of the international security environment, Montenegro is a beneficiary of a certain level of security, in regard with the decreased security threats in the region as a result of the integration of most of the countries from SEE in NATO, but just like any other country, in the future it could be exposed to asymmetrical, security risks and threats. Accordingly, the identified contemporary risks and threats can have an influence on Montenegro as well, which are: international terrorism and proliferation of weapons of mass destruction, religious and ethnic conflicts, international organized crime, illegal migration, drug smuggling and human trafficking [Strategija odbrane Crne Gore ("Sl. list Crne Gore", br. 79/08 od 23.12.2008)]. 
It could be concluded that Montenegro managed to build a modern national security concept in the recent years, which from the aspect of providing peace and security in the country and in the international community can respond to the challenges and the threats in the new security environment. This concept declines the accentuated or even the exclusive militarized approach, yet the significance and the role of the active foreign policy and diplomacy are primarily emphasized in it, thereafter the defence policy and the cooperation of the country with the civil society in providing security for the people and certainly, the opportunity to utilize the benefits of the NATO membership.

\section{NATIONAL SECURITY SYSTEM}

The system for national security of Montenegro constitutes the functional unity of all the elements in the country for the provision of protection of the national interests and values. Montenegro gives special importance to the role of civil society, civil military and civil - police cooperation in the field of security, as well as development of the civil sector and the sole national security institutions themselves.

In that context, Montenegro develops a functionally integrated system of national security, which provides:

1. Efficient functioning of the elements of the system in all conditions for provision of protection of the interests and values of Montenegro;

2. Interoperability of the elements of the national security system and rational resource utilization;

3. Coordination and efficient management of the national security system;

4. Equivalent development of all the elements in the system;

5. Transparent work of all the elements in the system;

6. Necessary personnel expertise and capability of the country to act preventively in cases of challenges, risks and threats to the security and adequately respond to them;

7. Contribution to the regional and global security.

\section{STRUCTURE OF THE NATIONAL SECURITY SYSTEM}

The structure of the national security system is comprised of the institutions and organs of the state which manage, plan, organize, adjust and accomplish the measures and activities of the security system.

Basic elements of the national security system, in addition to the Parliament of Montenegro, the President of the Republic, the Government, Council for defence and 
security, are the Ministry of interior, the Ministry of defence, the security forces (army and police), the forces for emergency action, the National security agency, the prosecutions and courts.

The Ministry of interior conducts the internal affairs in a manner which provides every citizen equal protection and exercise of his rights and freedoms ascertained with the Constitution.

For the purpose of realization of that goal the ministry conducts numerous tasks which refer to: analytical monitoring of the condition and strategic planning in the realm of criminality, public order and peace, traffic security; surveillance and internal control over the performance of the police tasks and procedures, competence, lawfulness and efficient execution of the police work; proposing and use of the mechanisms for efficient combat against human trafficking; evidence of vehicles and drivers; protection of personal data; risk management, management of protection and rescue in emergency situations and management and remediation of the consequences deriving from emergency situations; matters related to civil protection, as part of the integrated system for emergency situations management; implementation of international agreements under the competence of the ministry; giving opinions on legal draft proposals and other regulations or general acts which are linked with the affairs and issues of the state authorities or local governance; national borders security, integrated border management, modernization and maintenance of the border passages and building of a medium term program and annual plans for border passage management; adjustment of the domestic regulations with the EU, as well as cooperation with international and regional organizations, etc. (Ministarstvo unutrašnjih poslova Crne Gore, O ministarstvo, 2018).

Within the framework of the Ministry of Interior, according to the Statute for internal organization and systematization of the Ministry of Interior as organizational units appear: Directorate for strategic - development affairs, Directorate for oversight, Directorate for civil rights and personal identification documents, Directorate for emergency situations and Directorate for international cooperation and European integrations (Pravilnikom o unutrašnjoj organizaciji i sistematizaciji Ministarstva unutrašnjih poslova Vlada Crne Gore, 2018). With the Statute for internal organization and systematization of the police management which came into force in January 2018, the organizational units of the Ministry of Interior also include: Department for personal data protection and free access to information, Department for internal police control, Department for internal revision, the Cabinet of the minister, Human resources and personnel affairs office, Office for information - communication technologies, cyber security and technical surveillance, Office for finance, general and auxiliary affairs.

Within the framework of the Ministry of Interior, in accordance with the legislative settlements in the part of the police work, the Police, which is established as an independent organ of the country's management administration, has a prominent role. The police administration performs tasks which are linked with: protection of the security of the citizens and the freedoms and rights designated by the Constitution; protec- 
tion of assets; criminal acts and violations prevention and detection; finding and apprehension of perpetrators of criminal acts and violations and their prosecution; maintaining public order and peace; provision of security on public gatherings and other civic assemblies; protection of persons and objects; traffic security monitoring and control; national borders surveillance and security and performance of border control; foreign citizens movement control and sojourn; provision of conditions for uninterrupted court work, maintenance of order, protection of persons and assets; criminalistics expertise and investigations, criminal and other records; international police cooperateon; creation of analysis, elaborates, studies for monitoring certain security threats; as well as other matters within its competence (Ministarstvo unutrašnjih poslova Crne Gore, 0 Upravi policije, 2018).

The Ministry of Defence of the Republic of Montenegro is formed as a classical state linear organ, with all the characteristics of a modern administrative sectoral organization, such as: individual leadership, political responsibility, hierarchical organization, field attachment, etc. the Ministry of Defence is led by a defence minister which in general has a duty to direct the management and to enforce the Government's decisions, which determines the political guidelines for the activities of the ministry and the organs in its composition.

Fundamentally, the Ministry of Defence resolves the administrative and professional issues which refer to the defence plan of the country; conducts assessment of military and other hazards; implements multilateral and bilateral cooperation in the field of defence; performs tasks in the realm of organization, equipping, armament, development and utilization of the Army, performs other activities in accordance with the Constitution and the laws as well.

Within the framework of the realization of defence matters, the Army and the General staff headquarters are located within the framework of the Ministry of Defence. The Army of Montenegro is the carrier of the defence and counterpoises an armed force which defends the independence, the sovereignty and the territory of the country of Montenegro. According to Article 2 from the Law on the Army of Montenegro, the Army of Montenegro is a professional defence force which safeguards the independence, sovereignty and territory of the country of Montenegro [Zakon o Vojsci Crne Gore ("Službeni list Crne Gore", br. 051/17 od 3.8.2017)]. The command in the Army is based on the principle of subordination, unity of command, with regard to the use of forces and resources, single ranking and duties for executing decisions, commands, orders of the superiors and the authoritative organs based on the law and other regulations (Zakon 0 Vojsci Crne Gore, Article. 35).

In addition to the police and the army of Montenegro, within the framework of the realization of security and defence, an appropriate place respectively belongs to the intelligence - security sector. The intelligence - security sector of Montenegro is composed of the Agency for national security as a state organ, the Department for military intelligence and security affairs, as an organizational unit of the Ministry of Defence, as well as certain organs of the state management which within the framework of 
the prescribed competences gather, process, utilize, exchange, keep and protect the intelligence - security data [Zakon o osnovama obavještajno bezbjednosnog sektora Crne Gore, ("Službeni list Crne Gore", br. 28/14), член 2].

The Agency for National Security (ANS) is a legal successor of the Office for state security within the Ministry of Interior of the Republic of Montenegro and counterpoises a security - intelligence office which is a segment of the security system of Montenegro. In a functional notion, the Agency for National Security is subordinated to the Government of the Republic of Montenegro, and the control of the lawfulness of the work is performed by the Parliament. ANS is responsible for the national security matters which refer to: protection of the constitutionally designated legal order, protection of the independence, sovereignty, territorial integrity and security of Montenegro; protection of the human rights and freedoms, as well as performing other tasks that are in the national security interest. As part of the security system of the Republic of Montenegro, ANS does tasks in its competence on the basis of the Constitutional framework and laws, and is politically and ideologically neutral in its work [Zakon o Agenciji za nacionalnu bezbjednost Crne Gore, ("Sl. list RCG", br. 28/05 od 5.5.2005, 86/09 od 25.12.2009, 73/10 od 10.12.2010, 20/11 od 15.4.2011, 08/15 od 27.2.2015)].

The Department for military intelligence and security affairs performs tasks related with military intelligence, counter intelligence and security matters. The Department is managed by a person designated by the Government at the proposal of the defence minister with a previously given opinion by the working group in the Parliament competent for this sector [Cf.: Zakon o odbrani ("Službeni list Republike Crne Gore", br. 47/07, Službeni list Crne Gore", br. 86/09, 88/09, 25/10, 40/11, 14/12 і 2/17), чл. 4042.]. The Department for military intelligence and security affairs within the Ministry of Defence gathers military intelligence, counter intelligence and security data from publicly accessible sources. For the purpose of conducting these tasks, the department can gather data from persons employed in the Ministry or in the Army, persons employed in the state organs and in the organs of the state governance, local governance, organizations, institutions, etc.

\section{Conclusion}

The altered nature of the security threats and risks conditioned the need for redefinition of the security policy of the Republic of Montenegro, and also imposed the adoption of new approaches toward security. Accepting such reality, Montenegro has to adapt to the new security realities for the protection of the national interests and for the guaranteeing of the optimal level of security for the citizens and for the society. Hence, the adjustment of the security system to the new security environment should not be motivated by some comprehensive development program, it rather has to be an expression and a result of the evident general comprehensive inclusion of all the subjects which are adapted for implementing the security policies and the interests of the national security of the country. 


\section{References}

Bakreski, O., Milošević, M. (2010). Sovremeni bezbednosni sistemi. Skopje: Autoprint.

Doncev, A. (2007). Sovremeni bezbednosni sistemi. Skopje: FON.

Milošević, M., Bakreski O. (2013). Bezbednosni sistemi-teorisko-konceptualni okvir. Novi Sad.

Mišović, S. (2013). Sistemi odbrane. Beograd: Fakultet bezbednosti.

Pravilnikom o unutrašnjoj organizaciji i sistematizaciji Ministarstva unutrašnjih poslova Vlada Crne Gore, 1 februar 2018 godine.

Savić, A. Bajagić, M. (2005). Bezbednosti sveta. Zemun: Viša škola unutrašnjih poslova.

Slaveski, S. (2009). Bezbednosi sistemi. Skopje: Evropski univerzitet.

Strategija nacionalne bezbjednosti, ("Sl. list Crne Gore", br. 75/08).

Strategija odbrane Crne Gore ("Sl. list Crne Gore", br. 79/08 od 23.12.2008).

Keković, Z. (2011). Sistemi bezbednosti. Beograd: Fakultet bezbednosti.

Zakon o Vojsci Crne Gore ("Službeni list Crne Gore", br. 051/17 od 03.08.2017).

Zakon o osnovama obavještajno bezbjednosnog sektora Crne Gore, ("Službeni list Crne Gore", br. 28/14).

Zakon o Agenciji za nacionalnu bezbjednost Crne Gore, ("Sl. list RCG", br. 28/05 od 5.5. 2005, 86/09 od 25.12.2009, 73/10 od 10.12.2010, 20/11 od 15.4.2011, 08/15 od 27. 2.2015).

Zakon o odbrani ("Službeni list Republike Crne Gore", br. 47/07, Službeni list Crne Gore", br. 86/09, 88/09, 25/10, 40/11, 14/12 i 2/17).

\section{Интернет-извори:}

CIA, The World Factbook: Montenegro. https://www.cia.gov/library/publications/theworld-factbook/geos/mj.html[Accessed April 4th, 2018]

Garašanin, M. (2018). Crna Gora do Doseljavanja Slovena. Montenegrina Digitalna Biblioteka Crnogorske Kulture [online] available at: http://www.montenegro.yu/ podaci/stanovnistvo.htm, [Accessed November $26^{\text {th }}$ 2017]

Ministarstvo unutrašnjih poslova Crne Gore, 0 ministarstvo, http://www.mup.gov.me/ ministarstvo/o_ministarstvu [Accessed April 10th, 2018]

Ministarstvo unutrašnjih poslova Crne Gore, O Upravi policije, http://www.mup.gov. me/upravapolicije/naslovna/Nadleznost_i_organizacija [Accessed April 10th, 2018]

Montenegro-Canada, Crnogorski popis, http://www.montenegro-canada.com/articles/ article/8030164/157725.htm [Accessed April 4th, 2018] 